\title{
Marketing Strategies of Selected Water Refilling Stations in Nueva Ecija, Philippines
}

\author{
Renato Virola
}

\author{
Nueva Ecija University of Science and Technology, Cabanatuan City, Philippines
}

\begin{abstract}
The study presented the marketing strategies of selected water refilling stations in Nueva Ecija. The study aimed to assess different marketing strategies with focus on product offering, pricing and promotion of the water refilling stations along with getting the satisfaction of the customers with the strategies. The descriptive method of research was utilized and the normative survey technique was used for gathering data. The study revealed that most of the water refilling stations used similar marketing strategies. In addition, lack of budget hinders the water refilling stations for having good marketing strategies. Furthermore, customers are satisfied with the product offering and pricing except to the promotional activities of the water refilling stations.
\end{abstract}

Keywords- Marketing, price, product, promotion, water refilling stations

\section{INTRODUCTION}

Not all water is safe to drink. Water in lakes and rivers can be polluted. It can have harmful chemicals or germs that cause disease. Long ago, many people living in cities got sick or died from drinking dirty water. People still get sick from drinking polluted water. Many poor people still do not have pure drinking water. Scientists have learned how to clean, or purify, drinking water. With the advent of modernization, man learned to develop technology on how to produce clean drinking water. These technology were introduced and later on commercialized and became a fast growing industry. The demand at the water refilling stations is now increasing. In Nueva Ecija, more number of water refilling stations are now operating with some of them operate other stations in nearby municipalities.

A water refilling business is one of the most popular ventures for those with little experience as an entrepreneur because it is simple to operate and has a steady demand (businesscoachphil.com, n.d.) With the growing competition, these water refilling stations must pay attention on their marketing strategies since customers are influenced with the promotion, price and their product offering.

According to Domingo (2018) marketing plays a very important role in the organization's success; it is a must to every organization to consider strategizing their different marketing practices.

The objective of this research is to explore marketing strategies in the industry in terms of product offering, pricing, and promotion along with the customers' satisfaction with such practices.

Information on water refilling stations' marketing strategies is available through both industry and academic publications but these sources offer a limited depth of understanding. Numbers of studies about companies marketing strategies have already been conducted. Despite of its growing importance, water refilling station businesses' marketing strategies remains an under researched area. A study that addresses this research gap is therefore necessary hence; the need for this study was realized.

\section{METHODOLOGY}

The questionnaire served as the instrument for collecting data. Owners of water refilling stations in were taken as respondents. Fifty customers who were at stations during the data gathering period comprised the customer respondents.

\section{RESULTS AND DISCUSSIONS}

1. Marketing Strategies

1.1 Product Offering

Table.1: Marketing Strategies of Water Refilling stations in terms of Product Offering

\begin{tabular}{|c|c|c|}
\hline PRODUCT OFFERING & $\begin{array}{c}\text { Weighted } \\
\text { Mean }\end{array}$ & Description \\
\hline $\begin{array}{l}\text { 1. Quality and safe } \\
\text { drinking water }\end{array}$ & 5 & Always \\
\hline $\begin{array}{l}\text { 2. Variety of water } \\
\text { products }\end{array}$ & 3.6 & Very Often \\
\hline $\begin{array}{ll}\text { 3. } & \text { Advanced } \\
\text { technology-based } \\
\text { equipments in } \\
\text { water processing }\end{array}$ & 4 & Very Often \\
\hline $\begin{array}{l}\text { 4. } \begin{array}{l}\text { Prompt courteous } \\
\text { service }\end{array}\end{array}$ & 4 & Very Often \\
\hline
\end{tabular}




\begin{tabular}{|c|c|c|c|}
\hline 5 & $\begin{array}{l}\text { Provides customer } \\
\text { information } \\
\text { service }\end{array}$ & 2.8 & Often \\
\hline & $\begin{array}{l}\text { Sanitation and } \\
\text { cleanliness of the } \\
\text { area and their } \\
\text { surroundings }\end{array}$ & 5 & Always \\
\hline 7. & $\begin{array}{l}\text { Proper } \\
\text { arrangement } \\
\text { facilities }\end{array}$ & 4 & Very Often \\
\hline Averag & weighted mean & 4.06 & Very Often \\
\hline
\end{tabular}

Consideration number 1 and 6 got a weighted mean of 5.00 and rated "Always". This denotes that they considered offering quality and safe drinking water to their customers as well as maintaining the sanitation and cleanliness inside their stations.

Consideration number 5 got a weighted mean of 2.08 and rated "Often". This denotes that they often provide customer information.

These are the main factors they considered in the operation of the business in order to attract and retain loyal customers. In the study conducted by Aguilar, et.al (2007), also proved that the two most common used marketing mix by the selected water-refilling stations in Mandaue City Cebu is product and place. They used often the brands of the product as marketing strategy.

\subsection{Pricing}

Consideration number 1 and 4 got a weighted mean of 4.80 and consideration number 5 got a weighted mean of 4.60 were rated "Always". This denotes that the management of the water refilling stations priced their water products based on cost and competitors along with considering the giving of discounts. As to the internal factors affecting their pricing decision, consideration number 1 and 3 got a weighted mean of 5.00 and 4.80, respectively and rated "Always". The results show that they consider profit and cost as internal factors in pricing.

Table.2: Marketing Strategies of Water Refilling stations in terms of Pricing

\begin{tabular}{|c|c|c|}
\hline PRICING & $\begin{array}{l}\text { Weighted } \\
\text { Mean }\end{array}$ & Description \\
\hline \multicolumn{3}{|l|}{$\begin{array}{l}\text { The management uses the } \\
\text { following means of pricing }\end{array}$} \\
\hline 1. Based on cost & 4.8 & Always \\
\hline 2. $\quad$ Based on demand & 4 & Very Often \\
\hline $\begin{array}{l}\text { 3. Psychological (e.g. } \\
\text { P 991.95,P399) }\end{array}$ & 3.2 & Often \\
\hline 4. $\quad$ Discount & 4.8 & Always \\
\hline
\end{tabular}

\begin{tabular}{|c|c|c|}
\hline $\begin{array}{l}\text { 5. Based on the price } \\
\text { of competitors }\end{array}$ & 4.6 & Always \\
\hline \multicolumn{3}{|l|}{$\begin{array}{l}\text { Internal factors affecting } \\
\text { pricing decision }\end{array}$} \\
\hline 1. Profit & 5 & Always \\
\hline 2. Available offer & 3.6 & Very Often \\
\hline 3. $\operatorname{Cost}$ & 4.8 & Always \\
\hline \multicolumn{3}{|l|}{$\begin{array}{l}\text { External factors affecting } \\
\text { pricing decision }\end{array}$} \\
\hline $\begin{array}{l}\text { 1. The market and } \\
\text { demand }\end{array}$ & 4 & Very Often \\
\hline $\begin{array}{l}\text { 2. Competitors price } \\
\text { and offer }\end{array}$ & 4.46 & Always \\
\hline Average weighted mean & 4.35 & Always \\
\hline
\end{tabular}

As to external factors affecting their pricing decision, competitors' price is the major consideration with a weighted mean of 4.46 and rated "Always".

\subsection{Promotion}

As to factors observed to capture and maintain customers' loyalty, considerations 1 and 3 got a weighted mean of 5.00 and rated "Always". This implies that giving discount as well as simple greeting would keep and win loyal customers.

Table.3: Marketing Strategies of Water Refilling Stations in terms of Promotion

\begin{tabular}{|c|c|c|}
\hline Promotion & $\begin{array}{l}\text { Weighte } \\
\text { d Mean }\end{array}$ & $\begin{array}{c}\text { Descriptio } \\
\mathrm{n}\end{array}$ \\
\hline \multicolumn{3}{|l|}{$\begin{array}{l}\text { Factors observed to capture } \\
\text { and maintain Customers' } \\
\text { loyalty }\end{array}$} \\
\hline $\begin{array}{l}\text { 1. Giving customers' } \\
\text { discount }\end{array}$ & 5 & Always \\
\hline $\begin{array}{l}\text { 2. Providing additional } \\
\text { assistance like free } \\
\text { delivery }\end{array}$ & 3.8 & $\begin{array}{l}\text { Very } \\
\text { Often }\end{array}$ \\
\hline $\begin{array}{l}\text { 3. Greeting customers } \\
\text { and being friendly }\end{array}$ & 5 & Always \\
\hline $\begin{array}{l}\text { 4. Giving souvenirs and } \\
\text { gifts }\end{array}$ & 1.2 & Never \\
\hline \multicolumn{3}{|l|}{$\begin{array}{l}\text { The management uses the } \\
\text { following promotion practice }\end{array}$} \\
\hline 1. Advertising & 1.8 & Never \\
\hline $\begin{array}{ll}\text { 2. } & \text { Sales promotion } \\
\text { (giving freebies) }\end{array}$ & 3.2 & Often \\
\hline 3. Public relation & 1 & Never \\
\hline 4. $\quad$ Publicity & 1.2 & Never \\
\hline Ways of advertising & & \\
\hline
\end{tabular}




\begin{tabular}{|c|c|c|}
\hline 1. Local radio & 1 & Never \\
\hline 2. Local newspaper & 1 & Never \\
\hline 3. $\quad$ Brochures distributed & 1 & Never \\
\hline $\begin{array}{l}\text { 4. Billboard/tarpaulin } \\
\text { nearby }\end{array}$ & 3.4 & Often \\
\hline Average weighted mean & 2.38 & $\begin{array}{c}\text { Sometime } \\
\text { s }\end{array}$ \\
\hline
\end{tabular}

As to their promotional practice, they often use sales promotion as promotion practice. Sales promotion got a weighted mean of 3.20. Meanwhile, the management of the stations never consider advertising, print media, public relation and publicity as a promotion practice.

As to their advertising practice, they often use billboards/tarpaulins. Billboards/tarpaulins got a weighted mean of 3.40. Meanwhile, the management of the stations never consider local radio, newspapers and brochures as advertising practices.

Owners/managers expressed that they give much thought and time to promotions since they are very important for their organization's success. The reason why they spend time to craft an innovative promotion strategy is to capture the attention of existing and prospective customer.

2. Marketing Problems encountered by the Water Refilling Stations

Table.4: Marketing problems encountered by Water Refilling Stations

\begin{tabular}{|c|c|c|c|}
\hline Problems & $\begin{array}{l}\text { Weighte } \\
\text { d Mean }\end{array}$ & $\begin{array}{c}\text { Descriptio } \\
n\end{array}$ & $\begin{array}{c}\operatorname{Ran} \\
k\end{array}$ \\
\hline 1. Budget & 5 & Always & 1 \\
\hline $\begin{array}{l}\text { 2. Lack of } \\
\text { transportation } \\
\text { and } \\
\text { communicatio } \\
\text { n utilities }\end{array}$ & 3.6 & $\begin{array}{l}\text { Very } \\
\text { Often }\end{array}$ & 3 \\
\hline $\begin{array}{l}\text { 3. Lack of } \\
\text { facilities }\end{array}$ & 3 & Often & 5 \\
\hline $\begin{array}{l}\text { 4. } \begin{array}{l}\text { Outdated } \\
\text { equipments }\end{array}\end{array}$ & 3.2 & Often & 4 \\
\hline $\begin{array}{ll}\text { 5. Insufficient } \\
\text { number of } \\
\text { employees }\end{array}$ & 3.8 & $\begin{array}{l}\text { Very } \\
\text { Often }\end{array}$ & 2 \\
\hline $\begin{array}{l}\text { Average weighted } \\
\text { mean }\end{array}$ & 3.72 & $\begin{array}{l}\text { Very } \\
\text { Often }\end{array}$ & \\
\hline
\end{tabular}

Budget is the major problem considered by them. Budget got a weighted mean of 5.00 and rated "very often". According to the owners, they do not have enough budgets for their promotions and upgrading their equipments or purchasing more advance technology for providing more quality water products to their customers.

\section{Customers' Satisfaction \\ Table.5: Customers' Satisfaction}

\begin{tabular}{|c|c|c|}
\hline Customer Satisfaction & $\begin{array}{l}\text { Weighted } \\
\text { Mean }\end{array}$ & Description \\
\hline \multicolumn{3}{|l|}{ On Product Offering } \\
\hline 1. Quality of product & 3.9 & $\begin{array}{c}\text { Much } \\
\text { Satisfied }\end{array}$ \\
\hline 2. Quality of service & 3.5 & $\begin{array}{c}\text { Much } \\
\text { Satisfied }\end{array}$ \\
\hline 3. Variety of products & 4.18 & $\begin{array}{c}\text { Much } \\
\text { Satisfied }\end{array}$ \\
\hline 4. Cleanliness & 4.08 & $\begin{array}{c}\text { Much } \\
\text { Satisfied }\end{array}$ \\
\hline 5. Accommodation & 3.96 & $\begin{array}{c}\text { Much } \\
\text { Satisfied }\end{array}$ \\
\hline Average weighted mean & 3.92 & $\begin{array}{c}\text { Much } \\
\text { Satisfied }\end{array}$ \\
\hline \multicolumn{3}{|l|}{ Pricing } \\
\hline 1. Price of products & 3.44 & $\begin{array}{c}\text { Much } \\
\text { Satisfied }\end{array}$ \\
\hline $\begin{array}{l}\text { 2. Acceptance to the } \\
\text { price }\end{array}$ & 3.98 & $\begin{array}{c}\text { Much } \\
\text { Satisfied }\end{array}$ \\
\hline Average weighted mean & 3.71 & $\begin{array}{c}\text { Much } \\
\text { Satisfied }\end{array}$ \\
\hline \multicolumn{3}{|l|}{ Promotion } \\
\hline $\begin{array}{l}\text { 1. The use of radio } \\
\text { advertising }\end{array}$ & 1 & $\begin{array}{c}\text { Not } \\
\text { Satisfied }\end{array}$ \\
\hline $\begin{array}{l}\text { 2. The use of discounts } \\
\text { as a promotion } \\
\text { strategy }\end{array}$ & 2.02 & $\begin{array}{l}\text { Moderately } \\
\text { Satisfied }\end{array}$ \\
\hline $\begin{array}{l}\text { 3. The use of local } \\
\text { newspaper }\end{array}$ & 1 & $\begin{array}{c}\text { Not } \\
\text { Satisfied }\end{array}$ \\
\hline $\begin{array}{l}\text { 4. The use of } \\
\text { billboard(s)/tarpauli } \\
n\end{array}$ & 2.58 & Satisfied \\
\hline $\begin{array}{l}\text { 5. The use of brochures } \\
\text { given to customers }\end{array}$ & 1.32 & $\begin{array}{c}\text { Not } \\
\text { Satisfied }\end{array}$ \\
\hline Average weighted mean & 1.58 & $\begin{array}{c}\text { Not } \\
\text { Satisfied }\end{array}$ \\
\hline Grand weighted mean & 3.07 & Satisfied \\
\hline
\end{tabular}

In terms of product offering, customers were all much satisfied with the quality of products and services, as well as to the cleanliness and accommodation. Product offering got a weighted mean of 3.92 and rated "Much Satis fied". 
In terms of pricing, customers were also much satisfied with the prices of products. Pricing got a weighted mean of 3.71 and rated "Much Satisfied".

In terms of promotion, customers were moderately satisfied with the discounts given by the stations and got a weighted mean of 2.02, while billboards/tarpaulin received "satisfied" rating from the customers with a weighted mean of 2.58. Other promotional tools such as radio, news papers and brochures/leaflets received "not satisfied" rating from the customers. This might because the stations never have these tools.

Overall, the above results show that customers are satisfied with the product offering, pricing and promotional activities of the water refilling stations with an overall weighted mean of 3.07 .

\section{CONCLUSIONS AND RECOMMENDATIONS}

The study revealed that most of the water refilling stations used similar marketing strategies. The lack of budget hindered the water refilling stations for having good marketing strategies. Meanwhile, customers are satisfied with the product offering and pricing except to the promotional activities of the water refilling stations. Thus, the water refilling stations must consider marketing strategies, especially on promotion. They should also allot budget for their marketing programs. Furthermore, they could provide additional services like free delivery and the likes.

\section{REFERENCES}

[1] Domingo, A.V. (2018).Product, pricing and promotional strategies of Restaurants in Nueva Ecija: An Assessment. International Journal of Advanced Engineering, Management and Science(ISSN: 24541311),4(11), 753-756. http://dx.doi.org/10.22161/ijaems.4.11.2

[2] Aguilar, G., Baguio J., Cantabaco, E., Fuentes, J. and Neri, A. (2007). Marketing strategies of the selected eater-refilling station at Mandaue City. 2007-2008. http://research1marketingstrategies.blogs pot.com/2007/10/marketing -strategies-of-selected-water.html? $\mathrm{m}=1$

[3] http://www.businesscoachphil.com/top-tips-for-yourwater-refilling-business 